\title{
A five-year content analysis of articles in the American Resort Development Association's Developments magazine (2002-2006)
}

Received (in revised form): 1 February 2008

\section{Monica Lynn Carpenter}

is a doctoral student in the Rosen College of Hospitality Management's Hospitality Education programme. Monica's field of specialisation is in the area of vacation ownership and strategic management of hospitality enterprises.

\section{Randall S. Upchurch}

previously was the graduate programme director of the Rosen College's Graduate Degree programmes at the University of Central Florida. Dr Upchurch has over 25 years of industry experience in the lodging industry, and his research interests centre on timeshare resort management, organisational culture, ethics and consumer behaviour.

\begin{abstract}
This study serves as baseline research for the industry to follow in terms of analysing historical trends so as to expand the knowledge base surrounding the vacation ownership industry through a content analysis of the American Resort Development Association's Developments magazine from the years 2002 to 2006. Further, this study classifies the articles into eight management functions in a proposed model based on the Chon et al.'s study. Further, based on the studies of Sheldon and Jogaratnam et al., the study will determine the intensely contributing authors to Developments magazine. The study also examines the range and scope of management functions based on the proposed model that is focused upon in the articles from Developments magazine during the years 2002-2006 as well as the intended audience of the articles.
\end{abstract}

\section{Keywords:}

vacation ownership industry, content analysis, Developments magazine, American Resort Development Association

Monica Lynn Carpenter Rosen College of Hospitality Management University of Central Florida Orlando

FL 32819, USA

Tel: +14079038178

Fax: +14079038105

E-mail: mlcarpen@mail.ucf.edu
Journal of Retail and Leisure Property (2008) 7, 149-160.

doi:10.1057/rlp.2008.7; published online 12 March 2008

\section{INTRODUCTION}

The vacation ownership industry, formerly known as the timeshare industry, has evolved over the years from its inception in the 1960s. As of January 2006 , there were 154,439 vacation ownership units located at 1,604 resorts 
in the United States alone, in addition to other global destinations 4.1 million households who owned at least one vacation ownership unit either through weekly intervals or points-equivalents (ARDA, 2005, 2007a).

The American Resort Development Association (ARDA), the industry's lobbying representative in Washington, DC, is a trade association established in 1969 that embodies both the vacation ownership and resort development industries. Today, ARDA boasts over 1,000 corporate members which range from companies that are privately held to those that are publicly traded and international corporations all of whom share the expertise of vacation ownership interests under the leisure real estate umbrella (ARDA, 2005, 2007a).

ARDA's membership base incorporates industry vendors, suppliers and consultants, resort management companies, owner associations (HOA's), in addition to the owners in conjunction with the ARDA Resort Owners Coalition (ARDA-ROC). Also included in the membership base are hospitality educators and students with an interest in the vacation ownership industry (ARDA, 2005, 2007b). In an effort to disseminate information specific to the vacation ownership industry to these respective stakeholders, ARDA publishes a trade journal titled Developments.

\section{Problem statement}

At present there is a paucity of information profiling research concerning the vacation ownership industry and to this end the information published in Developments has not been profiled to date. Therefore, the purpose of this thesis research is to capture the body of knowledge as reported by ARDA within this publication. In particular, the metrics collected in this study concerns who the authors of articles contained in the ARDA's Developments magazine are and the topics they are writing about using a proposed model that adapts the 1989 study conducted by Chon, Evans and Sutherlin and the 1992 study conducted by Crawford-Welch and McCleary. These studies were utilised in combination with the 1991 study conducted by Sheldon and the 2005 study conducted by Jogaratnam, Chon, McCleary, Mena and Yoo. As such, these studies have been chosen to as the model by which to evaluate the content reported in Developments. It should be understood that the adaptation of the combination of these studies is based on the research in the hospitality industry of which vacation ownership is a part.

\section{Purpose of the study}

There has been limited research in the area of the vacation ownership industry as to whom the leading authors are for Developments magazine and there has not yet been an in-depth analysis of the concentration of interest that has been written about over the years. The net result is that academics and practitioners do not have a firm knowledge base on which to make strategic or operational decisions. As a result, an analysis of the journals' content may show patterns and trends that may have been overlooked by the industry as a whole.

Chon et al. (1989) developed a model that classified articles from four hospitality journals into six management function areas: 
administration, operations/property management, marketing, human resources, research and development, and finance. Within each management function area, there were associated topics. Crawford-Welch and McCleary (1992) replicated this study. These studies, however, did not specifically address the vacation ownership industry. As a result, there are two significant pieces of information that have yet to be captured concerning the categorisation of (a) the broader management functions of developing and operating vacation ownership and (b) the specific operational activities concerning the vacation ownership resort and operations. The proposed adaptation of the Chon et al. (1989) model to reflect the broader management functions of developing and operating vacation ownership resorts (in italics) and their associated activities is depicted in Table 1. The reader should note that a seventh and eighth management function has been added to the proposed model since salesmanship and convention planning and awareness are important management functions in the vacation ownership industry. Note that the associated activities are a further delineation of article content under the broader management function areas and are based on The Timeshare Industry Resource Manual (ARDA, 2005).

\section{Significance of the study}

The significance of the study is that it will serve as baseline research for the industry to follow in terms of analysing historical trends so as to expand the knowledge base surrounding the vacation ownership industry. In turn, this analysis will also show whether there are patterns and trends emerging from the articles so that the ARDA and the industry as a whole may make certain the needs of all members are being addressed. Lastly, this study will also be an addition to the theoretical literature for both the vacation ownership industry and the hospitality industry as a whole. The findings should show that the vacation ownership industry has a management function that is somewhat unique to the industry as well as show where the concentration of interest in the articles lies relevant to the vacation ownership industry.

Table I: Proposed model based on Chon et al. (1989)

\begin{tabular}{ll}
\hline Administration: & $\begin{array}{l}\text { Risk management, crisis management, strategy planning, accounting, organisational } \\
\text { structure, communication, environmental trends, federal regulation, state regulation, } \\
\text { ethics, benevolence, international regulation }\end{array}$ \\
& $\begin{array}{l}\text { Land management, resort amenities, homeowners associations, property } \\
\text { inventories, rental management, safety and security, sanitation, owner satisfaction, } \\
\text { Operations/property }\end{array}$ \\
management: & $\begin{array}{l}\text { Vacation ownership marketing mix (place, product, price, promotion, people and } \\
\text { distribution channels), market research, branding, alliance, consumer education }\end{array}$ \\
Marketing: & $\begin{array}{l}\text { Recruitment strategies, training and employee development, employee benefits, job } \\
\text { satisfaction, employee retention }\end{array}$ \\
Human resources: & Technological advancement, information gathering and analysis, innovations \\
Research and development: & Project financing, appraisals, financial statements, consumer financing, resale financing \\
Finance: & Sales process, purchase contracts, \\
Salesmanship: & Workshops, philanthropy, awards, interaction, planning \\
Convention planning and &
\end{tabular}




\section{LITERATURE REVIEW}

\section{Information dissemination to ARDA members - Developments magazine}

In April of 1983, ARDA began a newsletter named Developments for its members in an effort to disseminate news from both the association and from the industry. Over the years, the industry grew and so did Developments. In January of 1986, Developments transformed from a newsletter into a monthly trade magazine for the vacation ownership industry (R. Upchurch, personal communication, 2 February 2007).

Developments magazine is published ten times per year with extended coverage on both the ARDA Annual Convention and Fall Conference. Developments magazine is available exclusively to members of the ARDA whose subscriptions are funded through membership dues (ARDA, 2007c). Some of the recurring columns in specialised areas are written by members who offer expertise within those areas. Examples of this include legal and regulatory, finance and technology. Other regular columns are written by the staff of the ARDA. All members are, however, encouraged to submit articles to the magazine.

There have been many changes made to Developments magazine over the years. The Editor-in-Chief has changed, regular columnists have come and gone, industry issues have changed, as has the layout of the magazine. Today, Developments is the leading trade magazine with columns addressing leaders, trends and special events of the vacation ownership industry (ARDA, 2005).

\section{Content analysis in the hospitality and tourism industry}

In the hospitality and tourism industry, there are several well-known studies involving content analysis. These studies began to appear in the hospitality literature in the late 1980s. For example, a content analysis was conducted of academic contributors based on what was, at the time, four major hospitality journals. These journals included the Cornell Hotel and Restaurant Administration Quarterly, International Journal of Hospitality Management, Hospitality Education \& Research Journal and FIU Hospitality Review (Weaver and McCleary, 1989). This topic was later revisited in 1990 (Weaver et al., 1990). The latter provided a table of 20 of the most active colleges based on the number of names appearing on publications in the four journals between the years 1983 and 1988.

Chon et al. (1989) conducted a content analysis using articles from four hospitality journals between the years 1967 and 1986. The four journals included the Cornell Hotel and Restaurant Administration Quarterly, Hospitality Education and Research Journal, International Journal of Hospitality Management and FIU Hospitality Review. They examined the focus of the articles by functional area by journal. The functional areas included marketing, finance, administration, operations, research and development, and human resources.

One study examined research in tourism utilising three journals (Sheldon, 1991). These journals included Annals of Tourism Research, Journal of Travel Research and Tourism Management. She examined the 
rankings of universities based on the number of instances authors appeared either as a primary or other author in the three journals, repeat author contributions based on the number of contributions to each of the three journals and geographical region of the contributions.

A study was conducted (Rutherford and Samenfink, 1992) to ascertain the rank of academic contributors in four journals by tabulating the number of total and adjusted appearances in each journal. These journals were the Cornell Hotel and Restaurant Administration Quarterly, International Journal of Hospitality Management, Hospitality Research Journal and FIU Hospitality Review. A follow-up study was conducted ten years later (Samenfink and Rutherford, 2002).

The study conducted by Chon et al. (1989) was replicated by examining the subject areas and research techniques used in five hospitality-related journals between the years 1983 and 1989. The five journals utilised were the Cornell Hotel and Restaurant Administration Quarterly, International Journal of Hospitality Management, FIU Hospitality Review, Hospitality Education and Research Journal, and Journal of Travel Research (Crawford-Welch and McCleary, 1992).

Another study examined academic influence based on the results of a citation analysis they conducted (Woods and Schmidgall, 1995). This study utilised the five major hospitality management journals at that time: Cornell Hotel and Restaurant Administration Quarterly, FIU Hospitality Review, Journal of Hospitality Management, Journal of Hospitality and Tourism Education and Journal of Hospitality and Management Research. In order to perform the citation analysis, they maintained a database that contained references in a main article. A follow-up study was conducted six years later (Woods and Schmidgall, 2001).

A content analysis of five hospitality journals was conducted from the years 1990 to 1996 utilising the Cornell Hotel and Restaurant Administration Quarterly, Hospitality Research Journal, International Journal of Hospitality Management, FIU Hospitality Review, and International Journal of Contemporary Hospitality Management. The study examined the subject matter of the main articles from the selected journals and the research methodology utilised in each article (Baloglu and Assante, 1999).

Lucas and Deery (2004) performed a content analysis of five hospitality journals from the years 2002 to 2003. The journals utilised were the International Journal of Hospitality Management, International Journal of Contemporary Hospitality Management, Cornell Hotel and Restaurant Administration Quarterly, International Journal of Hospitality and Tourism Administration and Journal of Hospitality and Tourism Management. This study used key words in an effort to describe human resource issues emerging from the literature.

In an effort to replicate the work of Sheldon (1991), Jogaratnam et al. (2005) conducted a study using three major academic tourism journals from the years 1992 to 2001. These three journals were Annals of Tourism Research, Journal of Tourism Research and Tourism Management. They too examined the rankings of universities based on the number of instances authors appear either as a primary or other author in the three journals, repeat author contributions based on the 
number of contributions to each of the three journals and geographical region of the contributions.

\section{Research questions}

1. Who are the leading authors of articles in Developments magazine between the years 2002 and 2006 ?

2. What is the distribution of author contributions by geographic region based on the location of the institution with which the author is associated?

3. What are the range and scope of management functions based on the proposed model that is focused upon in the articles from Developments magazine during the years 2002-2006?

4. What are the range, scope and evolution of management function activities based on the proposed model reported in the articles from 2002 to 2006 ?

5. Which states are represented in the articles from 2002 to 2006 ?

6. Is there a difference between the management functions when filtered by type of property?

\section{METHODOLOGY}

The sample for this study is all issues of Developments magazine from the years 2002 to 2006 inclusive. Even though Developments magazine came into existence in the 1980s, the years 2002-2006 inclusive were readily available for statistical purposes.

The sample of articles to be analysed for this study was determined by criterion purposive sampling. The reason for this type of sampling is a result of the popularity of purposive sampling in qualitative research. This type of sampling selects subjects due to a common characteristic such as theme (Patton, 1990). For this study, the criterion for selection was only those articles that were of full length, were noneditorial and were nonadvertisement.

The study analysed a total of 613 articles from the ARDA's Developments magazine from the years 2002 to 2006 in two phases. The first phase of the study was qualitative in nature where each article was classified by management function and its related subtopic as per the proposed model based on the Chon et al. (1989) study.

The second phase focused on the quantitative portion of the study. The concept behind quantitative content analysis is to answer research questions and to test relationships between the variables. Therefore, this phase included descriptive analysis of the data in an effort to answer research questions one to five. In addition, chi-square tests of independence were performed to determine whether there was a statistical significance between each management function and the type of property (branded versus independent) focused upon in the article (research question six).

Each article was read and categorised on an index card listed data as shown in Table 2. The researchers examined the presence of underlying patterns and trends affecting the vacation ownership industry through the 
Table 2: Listing of data extracted from each sample article

utilisation of the management functions and related activities based on the proposed model. It was believed that the management functions and related activities that are drawn from the articles based on the proposed model illustrated this. To maintain reliability and validity, the researchers consulted with experts in the vacation ownership industry as well as the ARDA offices in Washington, DC and Orlando, FL for any discrepancies in categorisation.

Based on the Sheldon (1991) and Jogaratnam et al. (2005) studies, to determine the intensely contributing authors (those authors with greater than five occurrences), the articles were tabulated by author occurrence. An occurrence was considered an article written by an author either solely or in a group. For example, if John Doe wrote one article solely and another article with Jane Doe, John Doe would have two occurrences. In order to determine the number of article contributions by geographic location, the geographic location of the author's institution was the determinant.

Additionally, other generalised descriptive analysis was conducted including the following:

Frequencies of management functions

Frequencies of management functions activities

Frequencies of the states represented in the articles

In order to confirm the frequencies of the proposed management functions, each management function was assigned its own variable and assigned a ' 1 ' for present in the article and a ' 2 ' for not present in the article and entered into the Statistical Package for Social Science (SPSS). The results were to answer research question three "what are the range and scope of management functions based on the proposed model that are focused upon in the articles from Developments magazine during the years 2002-2006?'

Additionally, all management function activities have been assigned their own variables and assigned a ' 1 ' for present in the article and a ' 2 ' for not present in the article and entered into the SPSS. The results were to answer research question four.

To ascertain which states are most frequently represented in the articles, the content analysis table had a column for each state including the District of Columbia. Those states that are represented in the article were assigned a numeric value of ' 1 '. Those states not represented in the article were assigned a numeric value of ' 2 '. The data were then entered into the SPSS. The results were to answer research question five.

In order to ensure whether the property focused upon in the articles was branded or independent, the property followed classifications as per 
the ARDA's timeshare handbook. The term 'branded' is designated by ARDA to signify a recognised, national or international hotel/resort company such as Marriott, Disney, Hilton, Wyndham and such or a timeshare brand such as SunTerra, BlueGreen, TrendWest (R. Upchurch, personal communication, 15 May 2007). The articles were assigned the numeric value of ' 1 ' for branded, ' 2 ' for independent, ' 3 ' for both and ' 4 ' for not present. The data were then entered into the SPSS.

\section{RESULTS AND DISCUSSION}

Based on both the Sheldon (1991) and Jogaratnam et al. (2005) studies, the intensely contributing authors (those authors with greater than five occurrences) have been listed in Table 3 . Most of the intensely contributing authors are from staff members of the ARDA offices in Washington, DC and Orlando, FL. The majority of the contributors not listed here were one-time authors because they were professionals within the vacation ownership industry. It is interesting to note, however, that there were 147 out of 613 articles (24 per cent) with no author listed.

The distribution of author contributions by geographic region based on the geographic location of the author's institution was 606 articles (98.9 per cent) written by national authors, six articles ( 1 per cent) written by international authors and one article ( 0.2 per cent) by one national author and one international author. While the total number of articles written by international authors was low, it is important to note that articles focusing on Mexico and the Caribbean only began to surface in 2003 with one issue dedicated to Mexico in 2003. We believe that this trend will continue as the vacation ownership industry becomes increasingly global.

The range and scope of the eight management functions based on the proposed model that is focused upon in the articles from Developments magazine during the years 2002-2006 are depicted in Table 4. While the number of articles and percentage of salesmanship represented was low, it

Table 3: Leading contributors to Developments magazine

\begin{tabular}{lll}
\hline Rank & Author & Number of occurrences \\
\hline 1 & & 27 \\
2 & Goodhope, Randy & 22 \\
3 & Zanini, Darla & 19 \\
4 & Wells, Christina & 16 \\
5 & Zentis, Jennifer & 15 \\
6 & Tostevin, Jason & 13 \\
6 & Boesch, Christine & 13 \\
8 & Lennon, Marge & 10 \\
8 & Madsen, Stephany & 10 \\
10 & Rotondo, Chantal & 9 \\
11 & Woolard, Sandra & 7 \\
12 & Sancrainte, Joseph & 6 \\
12 & Bohrod, Georgi & 6 \\
12 & Funk,W. John & 6 \\
15 & Kenninger, Judy & 5 \\
15 & Duff,Victoria & 5 \\
15 & Jones, Timo & 5 \\
15 & Mullan, Kathryn & 5 \\
15 & Rock, Brian & 5 \\
& Scavo, James J. & \\
\hline
\end{tabular}


Table 4: Range and scope of management functions

\begin{tabular}{lcc}
\hline Management function & Frequency & Per cent of articles \\
\hline Administration & 198 & 32.3 \\
Operations/property management & 66 & 10.8 \\
Marketing & 77 & 12.6 \\
Human resources & 61 & 10.0 \\
Research \& development & 74 & 12.1 \\
Finance & 36 & 5.9 \\
Salesmanship & 12 & 2.0 \\
Convention planning and awareness & 89 & 14.5 \\
\hline
\end{tabular}

Table 5: Range and scope of management function activities

\begin{tabular}{|c|c|c|c|c|c|}
\hline Activity & Articles & Per cent & Activity & Articles & Per cent \\
\hline Risk management & 7 & 1.1 & Branding & 5 & 0.8 \\
\hline Crisis management & 4 & 0.7 & Consumer education & 6 & 1.0 \\
\hline Strategy planning & 40 & 6.5 & Recruitment strategies & 5 & 0.8 \\
\hline Accounting & 5 & 0.8 & Training/employee development & 48 & 7.8 \\
\hline Communication & 23 & 3.8 & Employee benefits & 4 & 0.7 \\
\hline Environment trends & 2 & 0.3 & Job satisfaction & 5 & 0.8 \\
\hline Federal regulation & 30 & 4.9 & Employee retention & 1 & 0.2 \\
\hline State regulation & 30 & 4.9 & Technological advancement & 44 & 7.2 \\
\hline International regulation & 4 & 0.7 & Information gathering/analysis & 18 & 2.9 \\
\hline ARDA code of ethics & 2 & 0.3 & Innovations & 12 & 2.0 \\
\hline Benevolence & 14 & 2.3 & Project financing & 16 & 2.6 \\
\hline Resort amenities & 15 & 2.4 & Appraisals & I & 0.2 \\
\hline Homeowners associations & 7 & 1.1 & Financial statements & 3 & 0.5 \\
\hline Property inventories & 1 & 0.2 & Consumer financing & 14 & 2.3 \\
\hline Rental management & 6 & 1.0 & Sales process & 12 & 2.0 \\
\hline Safety and security & 7 & 1.1 & Workshops & 20 & 3.3 \\
\hline Sanitation & 1 & 0.2 & Philanthropy & 12 & 2.0 \\
\hline Owner satisfaction & 10 & 1.6 & Planning & 7 & 1.1 \\
\hline Exchange services & 4 & 0.7 & Awards & 27 & 4.4 \\
\hline Architecture/design & 12 & 2.0 & Interaction & 22 & 3.6 \\
\hline \multicolumn{2}{|c|}{ Vacation ownership marketing mix 56} & 9.1 & & & \\
\hline
\end{tabular}

is important to note that sales and marketing has been combined. Only recently has salesmanship begun to emerge on its own.

The range and scope of the management function activities based on the proposed model that is focused upon in the articles from Developments magazine during the years 2002-2006 are depicted in Table 5. It is important to note that the management function activities are listed in the order of their corresponding management function.

As can be seen in the above table, there is a heavy emphasis on the vacation ownership marketing mix, training and employee development, technological advancement and strategy planning. The ARDA prides itself on the various training and educational programmes for those professionals in the vacation ownership industry. The representation for information gathering and analysis is, however, low. This suggests that there is an opportunity for academia and the vacation ownership industry to collaborate more closely in the future.

An interesting finding is that articles on federal and state regulation only account for 4.9 per cent of the total articles. This suggests that there 
may be a window of opportunity for further information dissemination to the ARDA members.

Another interesting finding is the emergence of consumer education articles in the last year or two. While this is only 1 per cent of the total articles, this is an area of interest that will continue to grow over time.

Table 6 depicts the representation of each individual state and the District of Columbia. It should come as no surprise that Florida, California, Nevada, Hawaii and South Carolina top the list as they are the five leading destinations in the vacation ownership industry.

Finally, a chi-square test of independence examined whether there was a significant difference between each management function when filtered by the property type. There was a statistically significant difference between the administration management function when filtered by property type; Pearson $\chi^{2}(3, N=613)=9.19, p=0.027$, $\varphi=0.122$. There was a statistically significant difference between the operations/property management function when filtered by property type; Pearson $\chi^{2}(3, N=613)=17.59, p=0.001, \varphi=0.169$. There was a statistically significant difference between the marketing management function when filtered by property type; Pearson $\chi^{2}(3, N=613)=12.07$, $p=0.007, \varphi=0.140$. There was no statistically significant difference between the human resources management function when filtered by property type; Pearson $\chi^{2}(3, N=613)=1.827, p=0.609, \varphi=0.055$. There was no statistically significant difference between the finance management function when filtered by property type; Pearson $\chi^{2}$

Table 6: States by referenced articles

\begin{tabular}{|c|c|c|c|c|c|}
\hline State & $\begin{array}{l}\text { Referenced } \\
\text { Articles }\end{array}$ & Per cent & State & $\begin{array}{l}\text { Referenced } \\
\text { Articles }\end{array}$ & Per cent \\
\hline Florida & 167 & 27.2 & Ohio & II & 1.8 \\
\hline California & 99 & 16.2 & Maryland & 11 & 1.8 \\
\hline Nevada & 98 & 16.0 & Oregon & 10 & 1.6 \\
\hline Hawaii & 58 & 9.5 & Maine & 8 & 1.3 \\
\hline South Carolina & 48 & 7.8 & Kansas & 7 & 1.1 \\
\hline Arizona & 44 & 7.2 & Alaska & 7 & 1.1 \\
\hline New York & 42 & 6.9 & Vermont & 6 & 1.0 \\
\hline Colorado & 39 & 6.4 & Montana & 6 & 1.0 \\
\hline District of Columbia & 33 & 5.4 & Arkansas & 6 & 1.0 \\
\hline Texas & 32 & 5.2 & Alabama & 6 & 1.0 \\
\hline Missouri & 24 & 3.9 & Mississippi & 5 & 0.8 \\
\hline Illinois & 24 & 3.9 & Minnesota & 5 & 0.8 \\
\hline Virginia & 22 & 3.6 & New Mexico & 4 & 0.7 \\
\hline New Hampshire & 22 & 3.6 & Kentucky & 4 & 0.7 \\
\hline Massachusetts & 22 & 3.6 & Rhode Island & 3 & 0.5 \\
\hline Utah & 20 & 3.3 & Nebraska & 3 & 0.5 \\
\hline Pennsylvania & 20 & 3.3 & lowa & 3 & 0.5 \\
\hline New Jersey & 16 & 2.6 & Delaware & 3 & 0.5 \\
\hline North Carolina & 15 & 2.4 & Connecticut & 3 & 0.5 \\
\hline Georgia & 15 & 2.4 & West Virginia & 2 & 0.3 \\
\hline Washington & 14 & 2.3 & South Dakota & 2 & 0.3 \\
\hline Tennessee & 14 & 2.3 & Oklahoma & 2 & 0.3 \\
\hline Indiana & 13 & 2.1 & North Dakota & 2 & 0.3 \\
\hline Louisiana & 12 & 2.0 & Michigan & 2 & 0.3 \\
\hline \multirow[t]{2}{*}{ Wisconsin } & II & 1.8 & Idaho & 2 & 0.3 \\
\hline & & & Wyoming & I & 0.2 \\
\hline
\end{tabular}


$(3, N=613)=7.525, p=0.057, \varphi=0.111$. There was no statistically significant difference between the salesmanship management function when filtered by property type; Pearson $\chi^{2}(3, N=613)=0.264, p=0.967$, $\varphi=0.021$. Finally, there was a statistically significant difference between the convention planning and awareness management function when filtered by property type; Pearson $\chi^{2}(3, N=613)=15.708, p=0.001$, $\varphi=0.160$.

\section{IMPLICATIONS FOR FUTURE RESEARCH}

This study was conducted on articles written post-September 11, 2001. It is highly recommended that research on articles prior to 11 September 2001 be performed in an effort to compare and contrast the patterns and trends of the vacation ownership industry. Further, it is recommended to determine whether this model is generalisable among past Developments magazine articles as well as those in 2007 and beyond. Additionally, it is suggested to determine who the intensely contributing authors were from the 1980s to 2001. It would also be advisable to watch for new international authors to emerge as the vacation ownership industry continues to globalise.

\section{LIMITATIONS OF THE STUDY}

The limitations of this study were that only those issues from January 2002 to December 2006 were readily available to the researchers for statistical analysis.

\section{References}

ARDA (2005). The 2005 Timeshare Industry Resource Manual, ARDA International Foundation, Washington, DC.

ARDA (2007a). State of the vacation timeshare industry. Retrieved 5th May 2007 from http://www arda.org/AM/Template.cfm?Section-State_of_the_Industry.

ARDA (2007b). Who we are. Retrieved 5th May 2007 from http://www.arda.org/Content/ NavigationMenu/Membership/WhoWeAre/Who_we_are.htm.

ARDA (2007c). About Developments. Retrieved 18th June 2007 from http://www.arda.org/AM/ Template.cfm?Section=About_Developments.

Baloglu, S. \& Assante, L.M. (1999). A content analysis of subject areas and research methods used in five hospitality management journals. Journal of Hospitality and Tourism Research. 23(1), 53-69.

Chon, K.-S., Evans, M.R. \& Sutherlin, D. (1989). Trends in hospitality management literature: A content analysis. Hospitality Education and Research Journal. 13(3), 482-491.

Crawford-Welch, S. \& McCleary, K.W. (1992). An identification of the subject areas and research techniques used in five hospitality-related journals. International Journal of Hospitality Management. 11(2), 155-167.

Jogaratnam, G., McCleary, K., Mena, M. \& Yoo, J. (2005). An analysis of hospitality and tourism research institutional contributions. Journal of Hospitality and Tourism Research. 29(3), 356-371.

Lucas, R. \& Deery, M. (2004). Significant developments and emerging issues in human resource management. International Journal of Hospitality Management. 23(5), 459-472.

Patton, M.Q. (ed.) (1990). Qualitative Education and Research Methods, 2nd edn, Sage Publications, Newbury Park, CA.

Rutherford, D.G. \& Samenfink, W.H. (1992). Most frequent contributors to the hospitality literature. Hospitality Research Journal. 16(1), 23-39.

Samenfink, W.H. \& Rutherford, D.G. (2002). Most frequent contributors to the hospitality literature: A ten-year update. Journal of Hospitality and Tourism Education. 14(3), 5-15. 
Sheldon, P.J. (1991). An authorship analysis of tourism research. Annals of Tourism Research. 18, 473-484.

Weaver, P.A. \& McCleary, K.W. (1989). Academic contributors: An analysis of academic contributions to four major hospitality journals. Ohio Hospitality Journal. 2(May), 6-11.

Weaver, P.A., McCleary, K.W. \& Ferrar, A. (1990). Academic contributors to four major hospitality journals revisited. Hospitality and Tourism Educator. 2(3), 30-32.

Woods, R.H. \& Schmidgall, R.S. (1995). Hospitality's influential authors: Using citation analysis to evaluate the research and contributions of hospitality faculty and programs. Hospitality and Tourism Educator. 7(1), 33-39.

Woods, R.H. \& Schmidgall, R.S. (2001). Update of hospitality management education's most influential scholars: A citation analysis 1989-1999. Hospitality and Tourism Educator. 13(2), 4-11. 